\title{
NORMATIVITY
}

That one's preference ought to be the law is an all-too-common human conceit. This certainty of the correctness of one's own preferred values as universal norms has become particularly pronounced over the last quarter century as "natural law" has mounted an increasingly successful challenge to positivism in the domain of international law. If classical liberalism preached toleration of national difference by enshrining positivism as its lodestar, neoliberalism has challenged that ethos of "moral relativism," identifying in its place some purportedly bedrock universal norms. The idea that only a particularistic form of "democracy" or of "human rights," or of market-driven capitalism, not to speak of "the rule of law," exemplifies this pull toward some familiar uniformity in the description and attribution of value and purpose to international law. Recent developments in the West, notably the rise of so-called populism, remind us that the preferences of elites alone, however sincerely held, have never been sufficient to create a universal standard for all. If one norm supersedes all others, it is that difference will always govern, because it is the only genuine response to the variations and diversities of human experiences. To search for some overriding purpose or value is thus a misguided search for uniformity in an environment of constant change and differentiated necessities.

\section{Peace is the Fundamental Value that International Law Exists to Serve} doi:10.1017/amp.2017.66

\section{By Cecilia M. Bailliet*}

Hersch Lauterpacht set forth that international law should be functionally oriented toward both the establishment of peace between nations and the protection of fundamental human rights. ${ }^{1}$ This perspective was followed by Hans Kelsen, who authored Peace Through Law, reminding us that the pursuit of peace requires patience and commitment to international norms and legal institutions, such as international criminal tribunals, stating, "He who wishes to approach the aim of world peace in a realistic way must take this problem quite soberly, as one of a slow and steady perfection of the international order."2 Later on the work of Grenville Clark and Lois B. Sohn spanned three decades, pursuing "World Peace Through World Law" through which they envisioned the creation of a World Conciliation Board, a World Equity Tribunal, compulsory jurisdiction for the ICJ, transfer of primary responsibility for the maintenance of peace from the Security Council to the General Assembly, and world disarmament enforced by regional courts. ${ }^{3}$ Several of these topics are under renewed discussion at present, including reform of the Security Council, the value of conciliation in international law, and the new Treaty on the Prohibition of Nuclear Weapons. Some suggest that the fragmentation of international law into specialized subfields, such as trade law, human rights, etc. resulted in a dissipation of attention to broader, common aims such as peace, instead promoting specialized technical expertise within each realm. To the extent that contemporary international law engaged with peace, it focused on the subject of peace treaties and the role of relevant institutions, such as the United Nations and regional entities.

\footnotetext{
* Professor, Department of Public \& International Law, University of Oslo, Norway.

${ }^{1}$ Hersch Lauterpacht, The Grotian Tradition in International Law, 23 Brit. Y.B. Int'1 Law 1, 51 (1946).

${ }^{2}$ Hans Kelsen, Peace Through Law (1944); see also Mary Ellen O’Connell, Peace and War, in The Oxford Handbook of the History of International Law 272 (Bruno Fassbender \& Anne Peters eds., 2012).

${ }^{3}$ Grenville Clark \& Louis B. Sohn, World Peace Through World LaW (1958).
} 
One of the key problems we face when articulating peace as the fundamental value that international law exists to serve is that the international community appears to lack a universally accepted definition. $^{4}$

Within theory there are two components of peace. The first is negative peace, which refers to the absence of war or armed conflict. The majority of peace research has focused on this categoryexploring the prevention of war, termination of war, transition from war, etc. Within the UN Charter, this is encapsulated by Article 2(4): "Members shall refrain in their international relations from the threat or use of force against the territorial integrity or political independence of any state, or in any other manner inconsistent with the Purposes of the United Nations." It is important to note that the UN Charter sets forth the rule of prohibition of the use of force but provides two exceptions: self-defense in accord with Article 51 or authorization by the UN Security Council under Chapter VII. The current regime is one of realistic peace, which recognizes the exceptions, not principled peace, which is absolute, with no exceptions permitted. Indeed, much of the literature actually addresses these exceptions as well as the challenges presented by increased use of humanitarian intervention, responsibility to protect (R2P) actions, and recent use of military force against nonstate actors where host states are "unable or unwilling" to address terrorist threats, all of which suffer from questionable legality and legitimacy. The United Nations requires states to be "peace loving" in order to join; further, it indicates that states have an obligation to settle disputes by peaceful means according to Article 2(3) and sets forth a sequence where states first shall seek nonviolent dispute resolution according to Article 33. This is a part of the UN Charter that is often overlooked.

The second component is positive peace, which refers to cooperation between states and peoples, social justice, respect for human rights, including equality and nondiscrimination, and the elimination of structural violence that causes inequality, poverty, and exclusion. This was advocated by Johan Galtung, but later was correlated with communism or utopianism, and hence peace research returned to examining negative peace instead. It may be argued that there is a need to pursue positive peace policies. Article 55 of the UN Charter indicates that peace has inter- and intrastate dimensions and underscores the relevance of institutions to promote development and human rights as preconditions for peace. This links back to the Kantian vision of the triad of mutual democracies, development, and cooperation. We recognize the contribution of FAO, IFAD, UNESCO, WHO, ILO, World Bank, IMF, WTO DSM, UN Climate Change Regime and the UN Environment Programme, UN Oceans, the UN human rights committees, and UN programs addressing sustainable development and poverty reduction. The question is to what extent is the positive peace vision is altered by the recession of democracies in the world and the increased trend toward authoritarianism.

At present the normative evolution of peace is enjoying a renaissance within international law; it originally commenced with the concept of a principle of "peaceful coexistence" and more recently enjoyed formulation as a "right to peace." Both concepts have been included within recent output; hence I will juxtapose Russia and China's Joint Declaration on the Promotion of International Law with the Declaration on the Right to Peace adopted by the Third Committee of the UN General Assembly in November $2016 .^{5}$

\footnotetext{
${ }^{4}$ Promoting Peace Through International Law 2 (Cecilia Marcela Bailliet \& Kjetil Mujezinovic Larsen eds., 2015).

${ }^{5}$ The Declaration of the Russian Federation and the People's Republic of China on the Promotion of International Law (June 25, 2016), available at http://www.mid.ru/en/foreign_policy/position_word_order/-/asset_publisher/6S4RuXfeYlKr/ content/id/2331698; Declaration on the Right to Peace, UN Doc A/C.3/71/L.29 (Oct. 31, 2016), available at http://www.un. org/ga/search/view_doc.asp?symbol=A/C.3/71/L.29.
} 
International law theorists including Grotius, Pufendorf, and Vattel articulated the concept of a natural right to peaceful coexistence that influenced Kant's vision of perpetual world peace brought about by a world federation of republics that renounced war. Peaceful coexistence was later further developed during the period of decolonization. Specifically, Five Principles of Peaceful Coexistence were identified in the Sino-Indian Agreement of 29 April 1954: (1) Mutual Respect for Territorial Integrity and Sovereignty, (2) Non-Aggression, (3) Non-Interference in Internal Affairs, (4) Equality and Mutual Benefit, and (5) Peaceful Coexistence itself. The principles of peaceful coexistence were later adopted within the Bandung Declaration on Promotion of World Peace and Cooperation at the 1959 Asian-African Conference. Peaceful coexistence is more often identified with negative peace rather than positive peace, and its components have been adopted within the UN Charter (Article 2) and the 1970 UN Declaration on Principles of International Law Concerning Friendly Relations and Cooperation Among States, now considered customary international law.

\section{Joint Statement on the Promotion of International Law}

On June 25, 2016, Russia and China issued a Joint Statement on the Promotion of International Law, which refers to the Principles of Peaceful Coexistence. It reaffirms sovereign equality, prohibition of the threat or use of force in violation of the United Nations Charter, nonintervention in the internal or external affairs of states, noninterference by states in the internal affairs of other states with the aim of forging change of legitimate governments, and the peaceful settlement of disputes, including respect for political and diplomatic means. In addition, Russia and China express condemnation of unilateral military interventions and extraterritorial application of national law by states not in conformity with international law. The acknowledgement of these standards as constitutive elements is significant because it provides a measure to exchange views on state behavior, including their own. Peaceful coexistence has reentered the vocabulary of even Western government officials, such as Germany's minister of defense, Ms. Von der Leyen, in reference to the Minsk Agreements on the Russian-Ukrainian crisis: "[w]hat's important is that we Europeans take our stand: respecting other countries' sovereignty and borders is essential for peaceful coexistence." "This is a strategic recognition of the articulated value in order to buttress negotiation to end violence and transition to peace.

Criticism has been offered that the Joint Statement does not refer to human rights, self-determination, or democratic legitimacy and may be interpreted as opposing humanitarian interventions and R2P actions. ${ }^{7}$ However, I suggest that the Joint Declaration should be read as a commitment to limiting expansion of the exceptions to the prohibition of the use of force, and hence in keeping with the UN Charter.

At the same time as the reemergence of peaceful coexistence, NGOs were promoting recognition of a Declaration on the Right to Peace within the UN General Assembly.

\section{The Declaration on the Right to Peace}

The initiative to promote recognition of a "right to peace" began with its characterization as a solidarity right, similar to the right to development, and was adopted in various resolutions by the UN General Assembly, dating back to the 1978 Declaration on the Preparation of Societies for Life

\footnotetext{
${ }^{6}$ Handelsblatt Interview: Von der Leyen: We Must Stand United, HandelsBlatt GLOBAL (Jan. 23, 2017), available at https://global.handelsblatt.com/politics/von-der-leyen-we-must-stand-united-687609.

${ }^{7}$ See Ingrid Weurth, China, Russia, and International Law, LAWfare Blog (July 11, 2016), available at https://www. lawfareblog.com/china-russia-and-international-law.
} 
in Peace. Renewed engagement by NGOs throughout the years culminated in 2016 when the Third Committee of the General Assembly approved the Declaration of the Right to Peace.

\section{Preamble}

The Declaration has a lengthy preamble which refers to both negative and positive elements of peace. It refers to the principles of prohibition of the threat or use of force against the territorial integrity or political independence of any state, peaceful settlement of disputes, the obligation of nonintervention, cooperation, equal rights and self-determination of peoples, and sovereign equality. Further, it deplores terrorism and expresses that "peace and security, development and human rights are the pillars of the United Nations system and the foundations for collective security and well-being, and recognizing that development, peace and security and human rights are interlinked and mutually reinforcing." It calls for attention to peaceful communication, "[r]ecognizing that peace is not only the absence of conflict but also requires a positive, dynamic participatory process where dialogue is encouraged and conflicts are solved in a spirit of mutual understanding and cooperation, and socioeconomic development is ensured."

The Preamble appears to adopt a liberal perspective by referring to human dignity as a fundamental principle: "[r]ecalling that the recognition of the inherent dignity and the equal and inalienable rights of all members of the human family is the foundation of freedom, justice and peace in the world, and recognizing that peace is promoted through the full enjoyment of all inalienable rights derived from the inherent dignity of all human beings."

\section{Operative Paragraphs}

The operative paragraphs of the Declaration are short. Article 1 states: "[e]veryone has the right to enjoy peace such that all human rights are promoted and protected and development is fully realized." Although the phrasing of the right implies a negative right that shall not be interfered with by the state, it may also be argued that it implies a positive obligation upon the state to ensure that the person benefits from the condition of peace. Hence, peace may be regarded as a type of meta-right, like security, which enables the person to enjoy human rights. Indeed, Hilary Charlesworth and Christine Chinkin suggested that ideally the right to peace should be jus cogens. ${ }^{8}$ The focus on the individual as the subject of the right may be interpreted as a possible orientation toward liberalism. From this perspective, peace is set forth as a necessary foundation that enables a person to live his or her life in dignity in pursuit of his or her aspirations.

On the other hand, a statist viewpoint would highlight the articulation of peace as a collective or communitarian aim (and development) that the state has an active role to pursue and the individual should support. Article 2 of the Declaration of the Right to Peace places primary responsibility on states to guarantee the structural framework necessary for individual enjoyment of both internal and external peace:

States should respect, implement and promote equality and non-discrimination, justice and the rule of law, and guarantee freedom from fear and want as a means to build peace within and between societies.

This recognizes the importance of strengthening the key components of positive peace policies and actually repeats identification of constituent rights that also pertain to the meta-right security: equality, freedom from fear, and freedom from want. A liberal interpretation would signal that this implicates legislative initiatives and engagement of an independent judiciary to protect

\footnotetext{
${ }^{8}$ Hilary Charlesworth \& Christine Chinkin, The Gender of Jus Cogens, 15 Hum. RTs. Q. 63 (1993).
} 
marginalized members of society. The statist view would emphasize the importance of maintaining the authority of the law as a means to guarantee peace; state action, rather than separation of powers, is seen as the vehicle for attainment of peace on behalf of collective society.

According to Article 3, the Declaration also recognizes a transnational framework for broad institutional enforcement of peace, rather than identifying specific remedies: the United Nations; specialized agencies; international, regional, national, and local organizations; and civil society are to support and assist the implementation of the Declaration. Universalists would argue that there is recognition that nonstate actors play an important role in guaranteeing peace (e.g., Google protecting "cyberpeace"); this is essentially expanding on Article 55 of the UN Charter, which underscores the role of specialized agencies to recognize economic and social welfare and protection of human rights as preconditions for peace. Statist approaches would interpret this to indicate that international organizations and civil society have an obligation to support the state in its pursuit of peace.

Article 4 perceives a transnational form for institutional promotion of peace:

International and national institutions of education for peace shall be promoted in order to strengthen among all human beings the spirit of tolerance, dialogue, cooperation and solidarity.

This indicates the realization that the attainment of peace requires a cultural change within societies in order to build trust, empathy, and skills for nonviolent dispute resolution. Statist regimes would highlight the values of cooperation and solidarity as strengthening communitarian policies.

It is important to note that Article 5 of the Declaration sets forth that its provisions are to be read in accordance with the UN Charter. Thus, it is implied that the UN Charter's exceptions to the prohibition of the use of force, i.e., self-defense in accordance with Article 51 and authorization by the UN Security Council under Chapter VII, would remain paramount. Hence, this is a declaration of realistic peace, rather than principled peace.

The voting record for this declaration is intriguing, as the majority of states in Latin America, the Middle East, Africa, and Asia (116) voted "Yes," including Afghanistan, Algeria, Brazil, China, Colombia, Congo, North Korea, India, Iran, Iraq, Russia, Syria, and Venezuela; while Western states (34) chose to vote "No," including Australia, Austria, Canada, Denmark, Finland, France, Germany, Israel, Sweden, United Kingdom, and the United States; and 19 states "Abstained," including Cyprus, Iceland, Italy, Norway, and Turkey.

In conclusion, we are witnessing shifts within international law, third generation rights such as the right to peace are being promoted, and peaceful coexistence has reentered the vocabulary of diplomats and international lawyers. I believe that we need to reorient legal education to research of the relevance of peace as a central aim of international law and explore how we can improve the institutions that have been created in pursuit of positive peace and nonviolent dispute resolution. There is no doubt that we face serious challenges, but it is important to sustain our attention to the positive evolution of international law. 